\section{Hivpositive som ønsker seg barn}

Hivpositive pasienter som deltok i en kvalitativ studie i Sør-Afrika søkte i liten grad råd fra helsepersonell om tryggere befruktning.

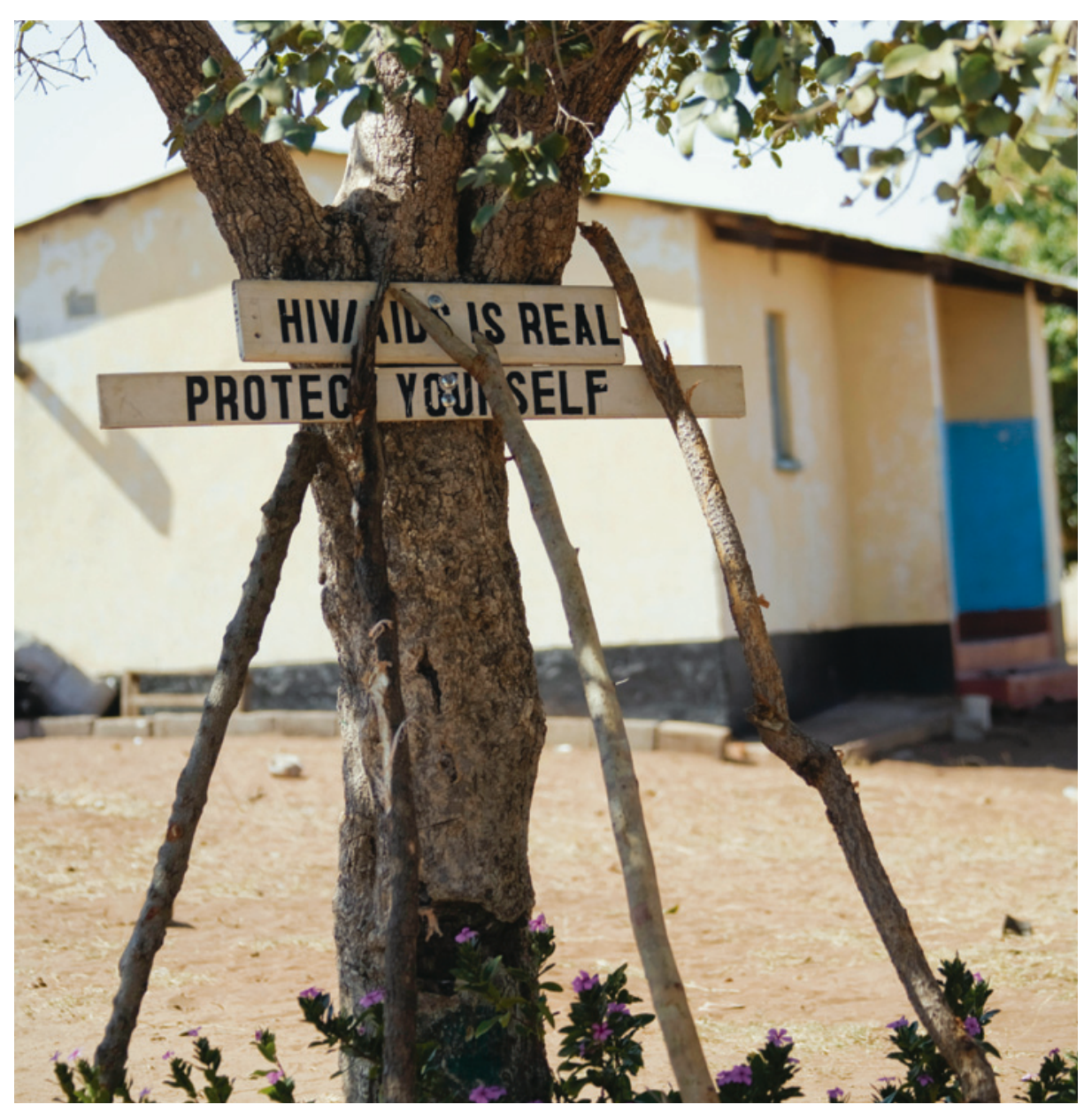

Illustrasjonsfoto Istockphoto

Ved en klinikk i Durban, Sør-Afrika, ble 50 hivpositive som oppga å ha hivnegativ partner intervjuet om sine erfaringer med reproduksjonsrådgivning. 30 kvinner som var eller nylig hadde vært gravide og 20 menn ble inkludert. De fleste oppfattet helsearbeidere som en god kilde til informasjon. Mange var blitt fortalt av helsearbeider at de burde søke mer informasjon på klinikken før de forsøkte å bli gravide, men de færreste hadde gjort det. Som begrunnelse for ikke å søke råd uttrykte enkelte redsel for fordømmelse fra helsearbeideren. Flere hadde ikke fortalt partneren om sin hivstatus, og parveiledning var da utelukket. En tredel av kvinnene fortalte at den aktuelle graviditeten var uplanlagt.

De deltakerne som hadde mottatt veileding om smittereduksjon ved unnfangelse, hadde fått høyst ulike råd. Mange nevnte kunstig befruktning og spermievasking som smittereduserende metoder - overraskende mange sett i lys av at dette var økonomisk utilgjengelig for deltakerne i denne studien. Samleie uten kondom begrenset til tiden rundt eggløsning, bruk av glidekrem og manuell inseminering ble også nevnt.

Forfatterne konkluderer med at helsearbeidere rutinemessig bør ta initiativ til å gi korrekt informasjon om hvordan pasientene best mulig kan redusere risikoen for smitte ved unnfangelsen.

\section{Øyunn Holen}

oeyhole@online.no

Mikrobiologisk avdeling

Bærum Sykehus

\section{Litteratur}

1. Matthews LT, Crankshaw T, Giddy J et al. Reproductive counseling by clinic healthcare workers in Durban, South Africa: perspectives from HIV-Infected men and women reporting serodiscordant partners. Inf Dis Obstet Gynecol 2012. E-publisert 15.8.

\section{Kan antall innleggelser reduseres?}

\author{
Samhandlingsreformen inne- \\ bærer at kommunehelsetjenesten \\ skal avlaste spesialisthelsetjenes- \\ ten. En studie av innleggelser fra \\ legevakt tyder på at det kan være \\ mulig.
}

Resultatene fra en prospektiv observasjonsstudie av akuttinnleggelser fra legevakt til sykehus er nylig publisert (1). Legevaktleger ble bedt om å angi fortløpende hvorvidt deres sykehusinnleggelser kunne vært unngått, gitt seks alternative helsetjenestetilbud. Alternativene var: innleggelse i distriktsmedisinsk senter, innleggelse i distriktspsykiatrisk senter, innleggelse i sykehjem, time ved spesialistpoliklinikk neste dag, intensiv hjemmesykepleie, observasjonsmulighet ved legevakten.

Studien ble gjennomført ved Værnesregionen legevakt, som er en interkommunal legevakt med et befolkningsgrunnlag på ca. 29000 mennesker. Datainnsamlingen fant sted første halvår av 2011 og omfattet 1083 legevaktkonsultasjoner, som resulterte i 152 innleggelser (14\%). 32 av innleggelsene (21\%) ble angitt som unngåelige. Innleggelse i distriktsmedisinsk senter, time ved spesialistpoliklinikk neste dag eller innleggelse i sykehjem var de mest aktuelle alternativene. De pasientene dette var aktuelt for, hadde i hovedsak sykdommer fra luftveiene eller mage-tarm-systemet.

Studien indikerer at nye samhandlingstiltak, slik som kommunale øyeblikkelig hjelp-senger i distriktsmedisinsk senter og/ eller sykehjem, kan bidra til å redusere antallet sykehusinnleggelser. I tillegg tyder resultatene på at spesialisthelsetjenesten bør utvide sitt akuttpolikliniske tilbud.

\section{Børge Lillebo \\ borge.lillebo@gmail.com \\ Værnesregionen legevakt}

Stjørdal

\section{Litteratur}

1. Lillebo B, Dyrstad B, Grimsmo A. Avoidable emergency admissions? Emerg Med J 2012. E-publisert 14.9 